\title{
Rodzaje aukcji na wytwarzanie energii elektrycznej z odnawialnych źródeł energii w świetle przepisów ustawy o odnawialnych źródłach energii
}

\section{Wprowadzenie}

Ustawa z dnia 20 lutego 2015 r. o odnawialnych źródłach energii ${ }^{1}$ wprowadza do polskiego systemu prawnego instytucję aukcji na sprzedaż energii elektrycznej z odnawialnych źródeł energii (dalej „aukcje OZE”), mającej tworzyć wysoce konkurencyjny instrument prawny, dzięki któremu wytwórcy będą mogli uzyskać wsparcie finansowe prowadzonej działalności gospodarczej². W związku z tym istotnym zagadnieniem prawnym jest analiza aktualnych przepisów u.o.z.e. wskazujących na sposób oraz zasady przeprowadzania poszczególnych aukcji OZE. Nowy zbiór przepisów dotyczących aukcji OZE, w ramach konkurencyjnych procedur, pozwala zakontraktować Radzie Ministrów wytworzenie w przyszłości określonego wolumenu energii elektrycznej z odnawialnych źródeł energii (dalej „OZE”), realizującego w ten sposób

${ }^{1}$ Dz.U. 2015, poz. 478 ze zm. (dalej „u.o.z.e.”).

${ }^{2}$ Zob. A. Stawicki, Komentarz do art. 39, w: Ustawa o odnawialnych źródłach energii. Komentarz, pod red. J. Baehra, P. Lissonia, J. Pokrzywniaka, M. Szambelańczyka, Warszawa 2016, s. 98-108; D. Kobiałko, Analiza ustawy o odnawialnych źródłach energii z 20 lutego 2015 roku w świetle przepisów unijnych dotyczących pomocy publicznej, „Przegląd Prawniczy Europejskiego Stowarzyszenia Studentów Prawa ELSA Poland" 2015, z. 3, s. 167-183; W. Szopiński, Czy systemy wsparcia dla energii z odnawialnych źródeł przewidziane w projekcie ustawy o odnawialnych źródłach energii można uznać za pomoc publiczną?, „Przegląd Prawniczy Europejskiego Stowarzyszenia Studentów Prawa ELSA Poland” 2015, z. 3, s. 153-166. 
cele polityki klimatyczno-energetycznej Unii Europejskiej (UE) ${ }^{3}$. Cele te wynikają z przepisów dyrektywy Parlamentu Europejskiego i Rady 2009/28/WE z dnia 23 kwietnia 2009 r. w sprawie promowania stosowania energii ze źródeł odnawialnych zmieniającej i w następstwie

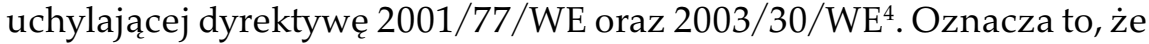
w aukcjach OZE co do zasady udział biora wytwórcy ${ }^{5}$, którzy dopiero zamierzają wybudować instalację OZE $\mathrm{OZ}^{6}$ Po przejściu odpowiedniego postępowania prekwalifikacyjnego ${ }^{7}$ oraz po zagwarantowaniu sobie odpowiedniego wsparcia operacyjnego, a więc de facto dopłat do wytwarzania energii elektrycznej ze źródeł kwalifikowanych jako OZE, wynikającego z aukcji OZE wytwórcy mogą podjąć racjonalną ekonomicznie decyzję o rozpoczęciu procesu inwestycyjno-budowlanego instalacji OZE. Podmiot, który zgłaszając projekt instalacji OZE, przegra taką aukcję, w ogóle nie musi jej budować, natomiast w przypadku jej wygrania uzyskuje ekonomiczne uzasadnienie swojej inwestycji, którą musi wybudować w ustawowo wskazanym terminie.

W tym aspekcie doniosłe znaczenie ma nowelizacja przepisów u.o.z.e. wprowadzona Ustawą z dnia 22 czerwca 2016 r. o zmianie ustawy o odnawialnych źródłach energii oraz niektórych innych ustaw ${ }^{8}$, która wprowadziła m.in. wymóg organizowania odrębnych aukcji OZE dla instalacji OZE charakteryzujących się wskazanymi w art. 73 ust. 3a pkt 1-7 u.o.z.e. parametrami. Przepis ten wprowadza podział na tzw. koszyki technologiczne, $\mathrm{w}$ ramach których organizowane będą odrębne aukcje OZE, w których będą mogły brać udział tylko wybrane instalacje

${ }^{3}$ Zob. A. Bohdan, M. Przybylska, Podstawy prawne OZE (odnawialnych źródeł eneroii) i gospodarki odpadami w Polsce, Warszawa 2015, Legalis/el.; A. Szafrański, Prawo energetyczne. Wartości i instrumenty ich realizacji, Warszawa 2014, s. 138-139, 231-233; R. Rybski, Dyrektywa w sprawie odnawialnych źródeł energii (energetyka), w: Implementacja prawa klimatyczno-energetycznego UE w Polsce, pod red. M. Stoczkiewicza, Warszawa 2013, s. 22-31.

${ }^{4}$ Dz.Urz. UE L 140 z 14 VIII 2009 r., s. 16.

${ }^{5}$ Szerzej na temat pojęcia wytwórcy zob. E. Kosiński, M. Trupkiewicz, Gmina jako podmiot systemu wspierania wytwarzania energii elektrycznej z odnawialnych źródeł energii, „Ruch Prawniczy, Ekonomiczny i Socjologiczny” 2016, z. 3, s. 102-105.

${ }^{6}$ Zob. definicja ustawowa zawarta w art. 2 pkt 13 u.o.z.e.

7 Zob. M. Trupkiewicz, Postępowania prekwalifikacyjne jako pierwszy etap udziatu w aukcjach OZE, „Studia Prawa Publicznego” 2017, nr 2, s. 101-122; J. Pokrzywniak, Komentarz do art. 71, w: J. Baehr, P. Lissoń, J. Pokrzywniak, M. Szambelańczyk (red.), Ustawa o odnawialnych źródłach energii. Komentarz, Warszawa 2016, s. 193-200; J. Pokrzywniak, Komentarz do art. 75, w: J. Baehr, P. Lissoń, J. Pokrzywniak, M. Szambelańczyk (red.), Ustawa o odnawialnych źródłach energii..., s. 214 i n.

${ }^{8}$ Dz.U., poz. 925. 
OZE. W związku z tym, celem niniejszego opracowania jest analiza prawna przepisów prawnych kształtujących wskazane powyżej „koszyki technologiczne" (kształtujące odrębne aukcje OZE) oraz wskazanie, jakiego rodzaju instalacje OZE będą mogły brać udział w poszczególnych rodzajach aukcji OZE. W analizowanym zakresie wykorzystane zostaną dotychczasowe prace doktryny prawa oraz inne materiały źródłowe, w tym pochodzące od organu regulacyjnego odpowiedzialnego za sektor elektroenergetyczny.

\section{Rodzaje organizowanych aukcji OZE}

Na samym wstępie niniejszego opracowania należy wskazać, że zgodnie $z$ art. 73 ust. 1 u.o.z.e. Prezes Urzędu Regulacji Energetyki (dalej „Prezes URE") ogłasza, organizuje i przeprowadza aukcje OZE nie rzadziej niż raz w roku. Nie wdając się w szczegółowe rozważania dotyczące charakteru prawnego aukcji OZE, co samo w sobie mogłoby być przedmiotem odrębnego opracowania, należy jedynie wskazać, że aukcje OZE są swoistym instrumentem prawnym z zakresu publicznego prawa gospodarczego, którego celem jest zachęcenie wytwórców do wytwarzania energii elektrycznej z OZE. Niewątpliwie stworzony przez ustawodawcę instrument prawny wykorzystuje cywilnoprawne rozwiązania dotyczące instytucji przetargu ${ }^{9}$, uregulowane w art. $70^{1}-70^{5}$ Ustawy z dnia 23 kwietnia 1964 r. Kodeks cywilny ${ }^{10}$. Można zatem wskazać, że aukcja OZE jest instrumentem hybrydowym w tym znaczeniu, że do norm prawnych o charakterze publicznoprawnym wprowadzono elementy rozwiązań właściwych dla prawa cywilnego. Sam termin "aukcja” użyty w u.o.z.e. ma znaczenie autonomiczne, specyficzne dla tego aktu prawnego. $\mathrm{W}$ istocie pojęciowo mamy do czynienia z konstrukcją bliższą przetargowi aniżeli aukcji.

Świadomie ograniczając przedmiotową analizę prawną jedynie do zagadnienia rodzajów poszczególnych aukcji OZE, należy wskazać, że zgodnie $z$ art. 73 ust. 3 u.o.z.e. Prezes URE przeprowadza odrębne aukcje na sprzedaż energii elektrycznej wytwarzanej w instalacjach OZE, o których mowa w art. 72 u.o.z.e. Na tej podstawie można wyróżnić instalacje OZE, które po raz pierwszy wytworzyły energię elektryczną

${ }^{9}$ Szerzej na temat przebiegu aukcji OZE zob. M. Trupkiewicz, Kilka uwag o Internetowej Platformie Aukcyjnej umożliwiającej uzyskanie wsparcia w zakresie odnawialnych źródet energii w kontekście podpisów elektronicznych, w niniejszym tomie, s. 117-133.

10 Tekst jedn. Dz.U. 2017, poz. 459 ze zm. 
przed dniem 1 lipca 2016 r. (dalej „stare instalacje”) oraz instalacje nowo projektowane, które nie wytworzyły energii elektrycznej przed wskazaną powyżej datą, a co do zasady wytworzą ją dopiero po wygraniu aukcji OZE (dalej „nowe instalacje”). Ponadto odrębne aukcje przeprowadza się również dla starych instalacji, które zostały zmodernizowane po dniu 1 lipca 2016 r., oraz dla nowych instalacji, które nie dość, że zostały uruchomione po dniu 1 lipca 2016 r., to po tej dacie będą także podlegać modernizacji polegającej na poprawieniu parametrów technicznych, szczegółowo opisanych $\mathrm{w}$ art. 74 ust. $2-5$ u.o.z.e. W związku z powołaną powyżej podstawą prawną z art. 73 ust. 3 u.o.z.e. należy wyróżnić cztery podstawowe rodzaje aukcji OZE, organizowanych odrębnie dla nowych instalacji OZE, zmodernizowanych nowych instalacji OZE oraz dla starych instalacji OZE i zmodernizowanych starych instalacji OZE.

Na marginesie powyższych rozważań należy wskazać, że stare instalacje OZE oraz zmodernizowane stare instalacje OZE mogą korzystać również z dotychczasowego systemu wspierania rozwoju odnawialnych źródeł energii, funkcjonującego przed dniem 1 lipca 2016 r., opartego na wydawanych przez Prezesa URE świadectwach pochodzenia, o których mowa w art. 44 i n. u.o.z.e. Niezależnie od tego wytwórcy ci mogą zdecydować się przejść do nowego systemu wsparcia realizowanego w drodze aukcji OZE, rezygnując tym samym z możliwości uzyskiwania świadectw pochodzenia. Aukcje dedykowane starym instalacjom OZE oraz zmodernizowanym starym instalacjom OZE zwykło się nazywać aukcjami migracyjnymi, pozwalającymi zmienić system wspierania danej instalacji OZE z formuły świadectw pochodzenia na mechanizmy wynikające z przepisów kształtujących system aukcji OZE. Należy również podkreślić, że instalacje OZE, które wytworzyły energię po dniu 1 lipca 2016 r., a więc nowe instalacje OZE oraz zmodernizowane nowe instalacje OZE, mogą korzystać jedynie z instrumentu wsparcia realizowanego $\mathrm{w}$ formie aukcji OZE.

Niezależnie od poczynionych powyżej zastrzeżeń ustawodawca zgodnie z art. 73 ust. 4 u.o.z.e. wskazuje, że aukcje OZE przeprowadza się odrębnie również dla instalacji OZE o łącznej mocy zainstalowanej elektrycznej nie większej niż $1 \mathrm{MW}$ oraz dla instalacji dysponującej łączną mocą zainstalowaną elektryczną powyżej $1 \mathrm{MW}$. Ponadto w art. 73 ust. $3 a$ w zw. $z$ art. 73 ust. 4 u.o.z.e. wskazano, że aukcje OZE przeprowadza się odrębnie dla siedmiu "koszyków technologicznych”, które będą przedmiotem szczegółowej analizy prawnej przedstawionej w kolejnej części niniejszego opracowania. 
Uwzględnienie wszystkich powołanych powyżej przepisów u.o.z.e. daje prawne podstawy, aby wskazać, że Prezes URE będzie mógł organizować aż 56 różnego rodzaju aukcji OZE, w których udział będą mogły brać poszczególne instalacje OZE spełniające szczegółowe parametry jednej bądź kilku aukcji OZE. Omówione rozróżnienie poszczególnych rodzajów aukcji OZE przedstawia poniższy schemat:

\section{Rodzaje aukcji OZE}

Instalacje OZE, które wytworzyły energię elektryczną przed dniem 1 lipca 2016 r.

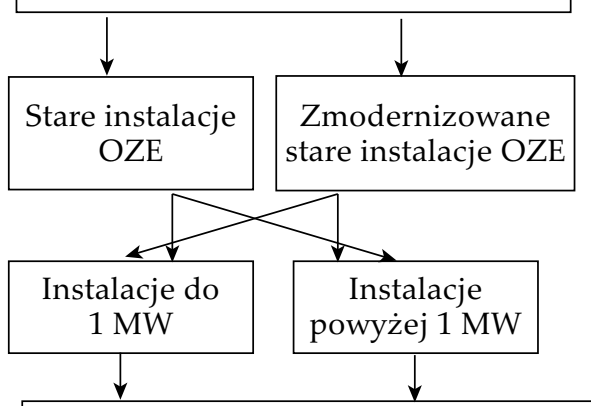

Instalacje OZE, które wytworzyły energię elektryczną po dniu 1 lipca $2016 \mathrm{r}$.

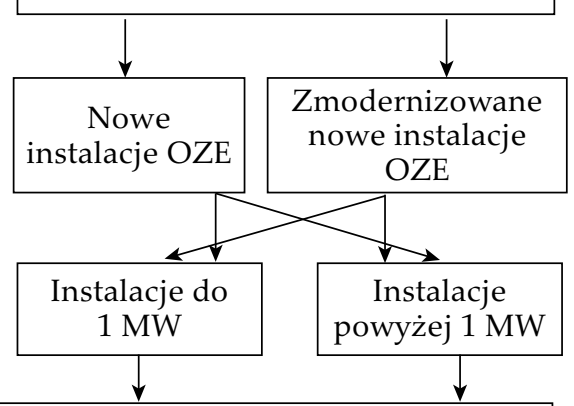

Aukcje dla instalacji OZE:

1) o stopniu wykorzystania mocy zainstalowanej elektrycznej, łącznej bez względu na źródło pochodzenia, większym niż $3504 \mathrm{MWh} / \mathrm{MW} / \mathrm{rok}$;

2) wykorzystujących do wytworzenia energii elektrycznej ulegająca biodegradacji część odpadów przemysłowych i komunalnych, pochodzenia roślinnego lub zwierzęcego, w tym odpadów z instalacji do przetwarzania odpadów oraz odpadów z uzdatniania wody i oczyszczania ścieków, w szczególności osadów ściekowych, zgodnie z przepisami o odpadach w zakresie kwalifikowania części energii odzyskanej z termicznego przekształcania odpadów;

3) w których emisja $\mathrm{CO}_{2}$ jest nie większa niż $100 \mathrm{~kg} / \mathrm{MWh}$, o stopniu wykorzystania mocy zainstalowanej elektrycznej większym niż 3504 $\mathrm{MWh} / \mathrm{MW} /$ rok;

4) zgłaszanych przez członków klastra energii;

5) zgłaszanych przez członków spółdzielni energetycznej;

6) wykorzystujących wyłącznie biogaz rolniczy do wytwarzania energii elektrycznej;

7) innej niż wymieniona w pkt 1-6. 
Na tym etapie prowadzonych rozważań należy wskazać, że Prezes URE będzie mógł skutecznie organizować poszczególne aukcje OZE jedynie w przypadku udostępnienia na te aukcje wolumenu energii elektrycznej szczegółowo określanego w rozporządzeniu corocznie wydawanym przez Radę Ministrów w sprawie maksymalnej ilości i wartości energii elektrycznej z odnawialnych źródeł energii, która może być sprzedana $\mathrm{w}$ drodze aukcji w danym roku kalendarzowym ${ }^{11}$ (dalej „rozporządzenie wolumenowe”). Oznacza to, że Rada Ministrów, prowadząc politykę wewnętrzną w zakresie kształtowania ilości oraz rodzaju wspieranych w Polsce odnawialnych źródeł energii, corocznie będzie wskazywać odpowiedni wolumen energii elektrycznej oraz jej kwotową wartość możliwe do rozdysponowania dla poszczególnych instalacji przygotowywanych do udziału w aukcji OZE organizowanej w następnym roku kalendarzowym. Delegację ustawową w tym zakresie zawiera art. 72 ust. 1 u.o.z.e., który wskazuje, że Rada Ministrów, $\mathrm{w}$ drodze rozporządzenia wydawanego w terminie do dnia 31 października każdego roku, określa maksymalną ilość i wartość energii elektrycznej z OZE wytworzonej oddzielnie w instalacjach mogących wziąć udział w jednym z 56 rodzajów aukcji OZE, wyodrębnionych na podstawie art. 72 ust. $1 \mathrm{w}$ zw. $\mathrm{z}$ art. 73 ust. $3 \mathrm{a} \mathrm{w} \mathrm{zw} . \mathrm{z}$ art. 73 ust. 4 u.o.z.e. Ponadto na podstawie art. 73 ust. 7 u.o.z.e. Rada Ministrów, tym razem na wniosek ministra właściwego do spraw energii, również w drodze rozporządzenia, określa kolejność przeprowadzania aukcji OZE, biorąc pod uwagę cel postawiony przed Polską wynikający z polityki klimatyczno-energetycznej UE w zakresie udziału OZE oraz potencjał w zakresie krajowych zasobów energii. Dopełnieniem powyższych przepisów wykonawczych jest wydawane na podstawie art. 77 ust. 1 u.o.z.e. przez ministra właściwego do spraw energii rozporządzenie określające poziom maksymalnej ceny w złotych za $1 \mathrm{MWh}$, za jaką może zostać sprzedana $\mathrm{w}$ danym roku kalendarzowym energia elektryczna wytworzona w ramach aukcji w poszczególnych rodzajach technologii OZE. W przedmiotowym rozporządzeniu minister właściwy do spraw energii określa także okres obowiązku zakupu energii oraz okres prawa do pokrycia ujemnego salda, będące szczegółowymi mechanizmami rozliczania środków finansowych przekazywanych w ramach realizacji zobowiązań wynikających z rozstrzygnięć aukcji OZE.

${ }^{11}$ Do tej pory na podstawie art. 72 ust. 1 u.o.z.e. wydano trzy tego typu rozporządzenia. 
Konkludując dotychczasowe rozważania dotyczące zasad przeprowadzania aukcji OZE, należy wskazać, że możliwość przeprowadzenia przez Prezesa URE odrębnych aukcji OZE w ramach poszczególnych „koszyków technologicznych" będzie uzależniona od treści rozporządzenia wolumenowego wskazującego, w jakich instalacjach może być wytworzona energia elektryczna z OZE, podlegająca wsparciu w ramach przeprowadzanych w danym roku aukcji OZE. W związku z tym należy podkreślić kluczową rolę owego rozporządzenia dla całego systemu wspierania odnawialnych źródeł energii. $\mathrm{W}$ tym zakresie należy również zwrócić uwagę, że to Rada Ministrów oraz minister właściwy do spraw energii kształtują zasady przeprowadzenia poszczególnych aukcji w danym roku kalendarzowym, co niewątpliwie wzmacnia ich pozycję w sektorze OZE i czyni odpowiedzialnymi za realizację założeń polityki klimatyczno-energetycznej UE ${ }^{12}$. Natomiast Prezes URE jako wyspecjalizowany w zakresie energetyki organ administracji rządowej został desygnowany jedynie do roli "administratora" czuwającego nad organizacją aukcji OZE, a także odpowiedzialnego za prawidłowy ich przebieg. Takie ukształtowanie zasad przeprowadzania aukcji OZE należy ocenić pozytywnie, choć dotychczasowa praktyka publicznego udostępniania inwestorom odpowiednich aktów prawnych realizujących założony przez rząd kształt polityki państwa w zakresie OZE pozostawia wiele do życzenia. Tak jak już wskazano, Rada Ministrów w terminie do dnia 31 października każdego roku określa wolumen energii elektrycznej w poszczególnych aukcjach OZE, która może zostać rozdysponowana w drodze aukcji OZE w następnym roku kalendarzowym. Abstrahując od terminu wydania dotychczasowych dwóch rozporządzeń w tym zakresie, które znacząco przekraczały zakreślony w ustawie termin, i tak należy wskazać, że jest on zbyt krótki, aby poszczególni inwestorzy mogli skutecznie powziąć informację dotyczącą przeprowadzanych w kolejnych latach aukcji OZE, a w związku z tym skutecznie przygotować odpowiednie projekty instalacji OZE. W tym zakresie de lege ferenda należałoby postulować przyjęcie przez Radę Ministrów dłuższej perspektywy organizacji i planowania aukcji OZE wskazujących, jakie technologie OZE mogłyby liczyć na uzyskanie wsparcia w ramach systemu aukcyjnego, tak aby inwestorzy skutecznie mogli przygotować swoje

${ }^{12}$ Zob. T. Długosz, Aukcja na sprzedaż energii elektrycznej wytwarzanej z odnawialnych źródeł energii wytworzonej w instalacjach odnawialnego źródta energii - nowy środek wspierajacy wybrany sektor gospodarki, w: Prawne instrumenty oddziatywania na gospodarkę, pod red. A. Powałowskiego, Warszawa 2016, s. 438-439. 
projekty instalacji OZE. Powyższe można osiągnąć albo poprzez zmiany ustawowe, obligujące Radę Ministrów do wydawania odpowiednich rozporządzeń z większym niż roczne wyprzedzeniem, albo też przyjęcie praktyki legislacyjnej polegającej chociażby na udostępniania opinii publicznej projektu rozporządzenia wolumenowego, choć jasne jest, że projekt miałby charakter jedynie poglądowy.

W dalszej kolejności, uwzględniając jednocześnie poczynione dotychczas ustalenia, należy przejść do szczegółowej analizy poszczególnych rodzajów aukcji OZE wskazanych w art. 73 ust. 3a pkt 1-7 u.o.z.e. Dokonując owej analizy, autorzy niniejszego opracowania wskazuja, jakiego rodzaju instalacje OZE będą mogły wziąć udział w danej aukcji, jeżeli będzie ona przeprowadzona, a także to, jakiego rodzaju zagrożenia natury prawnej wiążą się z możliwością uczestnictwa w danym rodzaju aukcji OZE.

\section{Prawna analiza poszczególnych rodzajów aukcji OZE}

Tak jak wskazano powyżej, odpowiedni wytwórcy rywalizują między sobą w aukcjach OZE o uzyskanie wsparcia prowadzonej działalności gospodarczej w zakresie wytwarzania energii elektrycznej z OZE. W związku z powyższym jednym z kluczowych wyzwań, z jakimi muszą się zmierzyć potencjalni wytwórcy, będzie konieczność zaplanowania odpowiedniej strategii pozwalającej na przystąpienie do właściwych aukcji OZE. W tym zakresie, oprócz wskazania podstawowych parametrów aukcji OZE związanych z podziałem na instalacje stare, nowe oraz zmodernizowane, a także uwzględnienia przedziałów mocy zainstalowanej w poszczególnych instalacjach OZE, tj. do $1 \mathrm{MW}$ oraz powyżej $1 \mathrm{MW}$, kluczowa staje się również analiza prawna „koszyków technologicznych", które dedykowane są określonego rodzaju instalacjom OZE, wykorzystującym różnego rodzaju źródła energii kwalifikowane jako źródła odnawialne. Po pierwsze, należy wskazać na odrębne aukcje OZE, w których będą mogły ze sobą konkurować instalacje OZE o stopniu wykorzystania mocy zainstalowanej elektrycznej, łącznej bez względu na źródło pochodzenia, większym niż $3504 \mathrm{MWh} / \mathrm{MW} /$ rok. W dużym uproszczeniu można wskazać, że ten rodzaj aukcji OZE dedykowany jest wszystkim instalacjom OZE charakteryzującym się cechą stabilności w procesie wytwarzania energii elektrycznej, a więc takim, które nie są nadmiernie uzależnione od działania naturalnych 
sił przyrody. Z osiągnięciem wskazanego powyżej limitu efektywności produkcji energii elektrycznej duże problemy będą miały instalacje korzystające z sił wiatru oraz promieniowania słonecznego, które w polskich warunkach atmosferycznych są w stanie wytwarzać energię odpowiednio w przedziale ok. $2500 \mathrm{MWh} / \mathrm{MW} /$ rok oraz ok. $1000 \mathrm{MWh} /$ $\mathrm{MW} /$ rok. Oznacza to, że instalacje wiatrowe oraz fotowoltaiczne nie będą mogły konkurować o uzyskanie wsparcia w ramach wolumenu energii elektrycznej udostępnionego w tego rodzaju aukcji OZE. Natomiast bez większych problemów parametr ten zostanie osiągnięty przez instalacje pracujące w systemie ciągłym, współspalające biomasę, biopłyn, biodegradowalne frakcje odpadów czy wykorzystujące różnego rodzaju biogaz do wytwarzana energii elektrycznej, w tym zwłaszcza biogaz pozyskany ze składowisk odpadów lub oczyszczalni ścieków, a także biogaz rolniczy. Instalacją OZE, która również mogłaby spełnić wskazany powyżej parametr cechujący instalacje stabilne, tj. 3504 MWh/ $\mathrm{MW} /$ rok, jest hybrydowa instalacja OZE, o której mowa w art. 2 pkt 11a u.o.z.e. Odpowiednie ukształtowanie parametrów technicznych takiej instalacji, łączących chociażby biogazownię rolniczą charakteryzująca się stabilnością produkcji na poziomie ponad $8000 \mathrm{MWh} / \mathrm{MW} /$ rok ze wspomnianymi już instalacjami wiatrowymi lub fotowoltaicznymi, pozwoliłoby takiej hybrydowej instalacji OZE na wzięcie udziału w tego rodzaju aukcji OZE ${ }^{13}$. Uwzględniając jednocześnie odrębne organizowanie aukcji OZE dla stabilnych instalacji o mocy zainstalowanej elektrycznej powyżej $1 \mathrm{MW}$, wydaje się, że aukcja ta zostanie zdominowana przez instalacje oparte na współspalaniu biomasy, która jest stosunkowo tańsza od innych "stabilnych" źródeł odnawialnych.

W związku z powyższym, uwzględniając charakter aukcji OZE rozstrzyganych na podstawie kryterium jak najniższej ceny, będą one miały największą szansę na zakontraktowanie wytworzenia określonej ilości energii w ramach tego rodzaju aukcji OZE. W tym aspekcie trzeba również wskazać, że w ramach tego rodzaju aukcji OZE szansę mogą mieć także różnego rodzaju biogazownie, zwłaszcza jeżeli rozporządzenia wolumenowe pozwolą na przeprowadzenie takiej aukcji dla instalacji do $1 \mathrm{MW}^{14}$.

${ }^{13}$ P. Krawczyk, M. Tarka, M. Trupkiewicz, Instalacje hybrydowe w świetle nowelizacji ustawy o OZE, „Czysta Energia” 2016, z. 10, s. 22-24.

${ }^{14}$ Autorom niniejszego opracowania nie jest znana instalacja OZE wykorzystująca współspalanie biomasy, która charakteryzowałaby się mocą przyłączeniową poniżej $1 \mathrm{MW}$, choć nie jest wykluczone, że instalacje takie mogłyby zostać utworzone. 
Kolejny rodzaj aukcji OZE, wskazany w art. 73 ust. 3a pkt 2 u.o.z.e., dedykowany jest instalacjom OZE wykorzystującym do wytworzenia energii elektrycznej ulegającą biodegradacji część odpadów przemysłowych i komunalnych pochodzenia roślinnego lub zwierzęcego, w tym odpadów $z$ instalacji do przetwarzania odpadów oraz odpadów z uzdatniania wody i oczyszczania ścieków, w szczególności osadów ściekowych, zgodnie z przepisami o odpadach w zakresie kwalifikowania części energii odzyskanej z termicznego przekształcania odpadów. W tak opisanej aukcji OZE organizowanej dla instalacji powyżej $1 \mathrm{MW}$ udział będą mogły wziąć instalacje przetwarzające biodegradowalne części odpadów przemysłowych bądź komunalnych na energię elektryczną. W aukcji dla instalacji powyżej $1 \mathrm{MW}$ będą to przede wszystkim instalacje termicznego przekształcania odpadów, będące spalarnią lub współspalarnią odpadów w rozumieniu Ustawy z dnia 14 grudnia 2012 r. o odpadach ${ }^{15}$, w których część wytwarzanej energii elektrycznej i ciepła pochodzi z ulegającej biodegradacji części odpadów przemysłowych lub komunalnych. W tego rodzaju aukcjach, zwłaszcza tych organizowanych dla instalacji do $1 \mathrm{MW}$, udział będą mogły wziąć również wszelkiego rodzaju biogazownie wykorzystujące jako paliwo substraty innego rodzaju niż te kwalifikowane jako biogaz rolniczy w rozumieniu definicji ustawowej wskazanej w art. 2 pkt 2 u.o.z.e. Oznacza to, że w ramach tej aukcji przewagę powinny osiągnąć biogazownie wykorzystujące m.in. biogaz pozyskany ze składowisk odpadów czy oczyszczalni ścieków, które ze względu na niższą cenę referencyjna, o której mowa w art. 77 ust. 1 u.o.z.e., będą bardziej konkurencyjne chociażby od biogazowni rolniczych. Nie oznacza to jednak, że w ramach tej aukcji udziału nie będą mogły wziąć biogazownie rolnicze, jeżeli wykorzystywać będą odpady z produkcji rolniczej spełniającej przesłanki definicyjne biogazu rolniczego. Niemniej wytwórcy planujący wykorzystanie biogazowni rolniczych będą musieli konkurować o wsparcie z innymi technologiami, np. biogazowniami na wysypiskach śmieci, a w związku z tym, chcąc wygrać aukcję OZE, zaoferować o wiele niższą cenę aukcyjną niż ta wynikająca z maksymalnej ceny referencyjnej dla biogazu rolniczego. Można jednak wskazać, że w przypadku braku wystarczającej liczby innych biogazowni wypełniających wolumen energii przewidzianej dla tej aukcji może ona okazać się równie atrakcyjna także dla biogazowni rolniczych, które przy braku dostatecznej konkurencji będą

\footnotetext{
15 Tekst jedn. Dz.U. 2016, poz. 1987 ze zm.
} 
mogły oferować ceny zbliżone do maksymalnych cen referencyjnych. W takim wypadku ten rodzaj aukcji OZE będzie stanowił atrakcyjną alternatywę dla aukcji OZE dedykowanych wyłącznie biogazowniom rolniczym, o których mowa w dalszej części niniejszego opracowania.

W kolejności należy zwrócić uwagę na następny rodzaj aukcji OZE, których parametry techniczne zostały uregulowane $\mathrm{w}$ art. 73 ust. 3a pkt 3 u.o.z.e. Opis parametrów technicznych instalacji OZE mogących wziąć udział w tej aukcji OZE wydaje się najbardziej problematyczny. Parametr stopnia wykorzystania mocy zainstalowanej na poziomie $3504 \mathrm{MWh} / \mathrm{MW} /$ rok przesądza, że chodzi o instalacje pracujące stabilnie, a więc takie, które nie są $\mathrm{w}$ nadmiernym stopniu uzależnione od działania sił przyrody, zwłaszcza od występowania wiatru oraz słońca. Drugim zasadniczym parametrem jest konieczność ograniczenia emisji $\mathrm{CO}_{2}$ na poziomie poniżej $100 \mathrm{~kg} / \mathrm{MWh}$, co uniemożliwia zgłaszanie ofert w tego rodzaju aukcjach OZE instalacjom opartym na spalaniu biomasy, biopłynów czy różnego rodzaju biogazu.

Prezes URE, dostrzegając pojawiające się w tym zakresie wątpliwości, zdecydował się na wydanie Informacji Prezesa Urzędu Regulacji Energetyki $\mathrm{Nr} 34 / 2017$ w sprawie zasad ustalania poziomu emisyjności $\mathrm{CO}_{2}$ na potrzeby aukcyjnego systemu wsparcia, o którym mowa w przepisach ustawy o odnawialnych źródłach energii ${ }^{16}$ (dalej „Informacja Nr 34/2017"). W dokumencie tym wskazano, że pod pojęciem emisji $\mathrm{CO}_{2}$ należy rozumieć rzeczywistą masę dwutlenku węgla powstałą w rezultacie całkowitego i zupełnego spalania paliw oraz wprowadzoną bezpośrednio do środowiska przez instalację OZE pracującą przy parametrach znamionowych podczas wytwarzania $1 \mathrm{MWh}$ energii elektrycznej mierzonej na zaciskach generatora. Prezes URE podkreślił, że do takiej emisji nie dochodzi w instalacjach ( $w$ tym również w instalacjach hybrydowych) wykorzystujących wyłącznie energię wiatru, promieniowania słonecznego, aerotermalna, geotermalna, hydrotermalną, hydroenergię oraz energię fal, prądów i pływów morskich. Ponadto Prezes URE wskazał dwie referencyjne metody obliczania poziomu emisji $\mathrm{CO}_{2}$ dla pozostałych źródeł odnawialnych, przy wykorzystaniu ustalonych w tym dokumencie wskaźników dla poszczególnych technologii.

W praktyce pojawiła się jednak wątpliwość, czy instalacje wykorzystujące różnego rodzaju paliwa kwalifikowane jako OZE, pomimo

${ }^{16}$ Zob. https://www.ure.gov.pl/pl/stanowiska/7043,Informacja-nr-34-2017.html (dostęp: 27 V 2017). 
przekroczenia poziomu emisji $\mathrm{CO}_{2}$, mogą podjąć inne działania mające na celu jej zmniejszenie do wymaganego poziomu, a w konsekwencji spełnić parametry techniczne omawianej aukcji OZE. Wskazany poziom emisji, przykładowo, mógłby być osiągnięty dzięki wyposażeniu biogazowni rolniczej czy instalacji wykorzystującej biomasę w urządzenia do całkowitego wychwytywania dwutlenku węgla, a następnie jego zagospodarowania i przetwarzania na potrzeby innych procesów gospodarczych, np. związanych z produkcją tzw. suchego lodu. O ile zatem sama instalacja emituje $\mathrm{CO}_{2}$ na poziomie wyższym niż $100 \mathrm{~kg} /$ MWh, to wyposażenie jej w urządzenia przekształcające tę emisję na dodatkowy produkt nie tylko powoduje zwiększenie przychodów, ale również minimalizuje samą emisję, umożliwiając zgłoszenie oferty w omawianym rodzaju aukcji OZE. Niemniej przyjęty w Informacji $\mathrm{Nr} 34 / 2017$ sposób ustalania pojęcia emisji $\mathrm{CO}_{2}$ sprawia, że urządzenia wychwytujące emisję $\mathrm{CO}_{2}$ traktowane są jako odrębna infrastruktura techniczna, niestanowiąca elementu wchodzącego w skład instalacji OZE. W związku z tym instalacja OZE emituje $\mathrm{CO}_{2}$ na charakterystycznym dla danej technologii poziomie, a dodatkowe urządzenia jedynie wychwytują oraz przekształcają wyemitowany już dwutlenek węgla. Należy zatem wskazać, że urządzenia do wychwytywania i przetwarzania $\mathrm{CO}_{2}$ stanowią dodatkowe urządzenia techniczne niewchodzące w skład instalacji OZE, o której mowa w art. 2 pkt 13 u.o.z.e. ${ }^{17} \mathrm{~W}$ konsekwencji kwestionuje się możliwość dopuszczenia do udziału w tego rodzaju aukcji instalacji OZE wyposażonych $w$ takie urządzenia. Prezes URE podkreślił również, że przy wyznaczaniu emisji $\mathrm{CO}_{2}$ nie obowiązują zerowe współczynniki $\mathrm{CO}_{2}$ stosowane w systemie handlu uprawnieniami do emisji gazów cieplarnianych, a także wielkość emisji unikniętej oraz ilość $\mathrm{CO}_{2}$ zaabsorbowanego przez wykorzystywaną biomasę.

W związku z powyższym w poszczególnych aukcjach OZE organizowanych w "koszyku technologicznym”, o którym mowa w art. 73 ust. 3a pkt 3 u.o.z.e., mogą brać udział źródła bezemisyjne, w szczególności instalacje wykorzystujące różnego rodzaju naturalne siły wód morskich i śródlądowych oraz energię geotermalną i aerotermalną, które nadto zdołają osiągnąć i utrzymać parametr stabilności na poziomie 3504 $\mathrm{MWh} / \mathrm{MW} /$ rok. Natomiast w przypadku instalacji stabilnych, wykorzystujących różne postacie biomasy, wytwórcy będą mogli tworzyć

${ }^{17}$ M. Trupkiewicz, M. Tarka, Problematyka rozbudowy istniejacej instalacji OZE wykorzystującej biogaz rolniczy, "Czysta Energia” 2016, z. 9, s. 12-14. 
instalacje hybrydowe, których indywidualnie obliczane parametry będą mogły zapewnić zarówno poziom emisji poniżej $100 \mathrm{~kg} / \mathrm{MWh}$, jak i stabilność pracy instalacji na poziomie $3504 \mathrm{MWh} / \mathrm{MW} /$ rok.

Przechodząc do analizy kolejnych rodzajów aukcji OZE, należy wskazać, że ze względu na znaczny poziom podobieństwa następne dwa rodzaje aukcji OZE, wskazane w art. 73 ust. 3a pkt 4 i 5 u.o.z.e., warto omówić łącznie. Chodzi tu o odrębne aukcje OZE, w których udział będą mogli brać jedynie członkowie klastra energii, o którym mowa w art. 2 pkt 15a u.o.z.e., oraz członkowie spółdzielni energetycznej, o której mowa w art. 2 pkt 33a u.o.z.e. Przede wszystkim warto podkreślić, że przepisy definiujące oba odrębne rodzaje aukcji OZE weszły w życie dopiero z dniem 1 lipca 2017 r., co z praktycznego punktu widzenia oznacza, że tego rodzaju aukcje będą mogły zostać przeprowadzone przez Prezesa URE najwcześniej z końcem trzeciego kwartału 2017 r., choć w tym zakresie należy również wskazać, że odpowiednie rozporządzenie wolumenowe dotyczące aukcji w 2017 r. nie przewiduje możliwości przeprowadzenia tego rodzaju aukcji OZE w 2017 r. Określenie stosunkowo długiego okresu vacatio legis tych przepisów oraz brak wolumenu na takie aukcje w 2017 r. związane jest z brakiem szczegółowych uregulowań prawnych określających zasady funkcjonowania spółdzielni energetycznych oraz klastrów energii, a w związku $z$ tym także instalacji OZE funkcjonujących w tych formach kooperatyw. Niezależnie od tego warto podkreślić, że w odróżnieniu od pozostałych rodzajów aukcji OZE wyróżnionych w art. 73 ust. 3a u.o.z.e. omawiane w tej części opracowania aukcje OZE kwalifikowane są podmiotowo, to znaczy ze względu na rodzaj podmiotów (uczestników klastra bądź spółdzielni) zamierzających wziąć udział w aukcji OZE, a nie ze względu na szczególne cechy przedmiotowe (technologiczne) instalacji OZE mogących brać w nich udział. Po uwzględnieniu dotychczasowej regulacji prawnej należy wskazać, że w aukcjach tych będą mogły brać udział wszystkie rodzaje instalacje OZE (odrębnie dla rodzajów aukcji OZE do $1 \mathrm{MW}$ oraz powyżej $1 \mathrm{MW}$ ), o ile inwestorami tego typu projektów będą członkowie klastra energii bądź spółdzielni energetycznych. Oznacza to, że konkurencja pomiędzy takimi podmiotami i ich instalacjami OZE w ramach każdej z tych aukcji może być dość znacząca. Możliwość uzyskania wsparcia będzie uzależniona w głównej mierze od technologii wykorzystywanej przez dany klaster lub spółdzielnię, co będzie determinować poziom ceny możliwej do zaoferowania w ramach danej aukcji OZE. Większe szanse powodzenia w ramach rywalizacji będą 
zatem mieli ci wytwórcy, którzy oprą swoje instalacje OZE na technologiach odpowiadających najniższej cenie referencyjnej lub uzyskają innego rodzaju pomoc publiczną pozwalającą obniżyć cenę zaoferowaną w aukcji OZE, przy jednoczesnym pożądanym przez wytwórców zachowaniu maksymalnego poziomu łącznej pomocy publicznej, o której mowa w art. 39 u.o.z.e.

Kolejny odrębny rodzaj aukcji OZE, wskazany w art. 73 ust. 3a pkt 6 u.o.z.e., dotyczy instalacji OZE wykorzystujących wyłącznie biogaz rolniczy do wytwarzania energii elektrycznej, a więc wyłącznie tzw. biogazowni rolniczych, które stanowią konglomerat urządzeń wskazanych w art. 2 pkt 13 lit. a i b u.o.z.e., tworzących jedną instalację OZE. Stworzenie odrębnego rodzaju aukcji OZE tylko dla jednego rodzaju odnawialnego źródła energii jest wyrazem preferencji ustawodawcy, którego ratio legis można doszukiwać się w dążeniu do zapewnienia dodatkowego stałego źródła przychodu podmiotom prowadzącym swoją działalność na wsi, a więc co do zasady rolnikom samodzielnie inwestującym w biogazownię lub dostarczającym jedynie substrat rolniczy. Systemowe wspieranie biogazowni rolniczych związane jest również z ograniczeniem obowiązków reglamentacyjnych związanych z warunkami podjęcia tego rodzaju działalności gospodarczej, a także z ustawowo gwarantowanym poziomem ceny 550 zł/MWh, która w poszczególnych latach może być określona jedynie na wyższym poziomie, o czym mowa w art. 77 ust. 2 u.o.z.e. Skonstruowanie przez ustawodawcę odrębnego rodzaju aukcji dedykowanych wyłącznie biogazowniom rolniczym także jest przejawem działań ustawodawcy, zachęcającego do prowadzenia tego typu działalności gospodarczej. Poziom konkurencji w tego rodzaju aukcjach OZE będzie zależał głównie od poziomu wolumenów przewidzianych na tego rodzaju aukcje, dla instalacji do albo powyżej $1 \mathrm{MW}$. Im większy wolumen zostanie przewidziany dla potencjalnych wytwórców, tym mniejsze znaczenie będzie uzyskiwał poziom cen oferowanych w tej aukcji OZE, której poziom będzie zbliżony do poziomu ceny referencyjnej.

Ostatnim rodzajem aukcji, w ramach którego przeprowadzane będą odrębne aukcje OZE, wskazanym przez ustawodawcę w art. 73 ust. 3a pkt 7 u.o.z.e., jest zbiorcza kategoria instalacji OZE innych niż te wymienione w art. 73 ust. $3 a$ pkt 1-6 u.o.z.e. (dalej „aukcje dla instalacji innych"). Można zasadnie przyjąć, że de facto będzie to najbardziej oblegana aukcja OZE, w której o wsparcie będą konkurować wytwórcy planujący wytwarzanie energii elektrycznej albo już ją wytwarzający 
w zupełnie różnych instalacjach OZE. Warto wskazać, że w tego rodzaju aukcjach OZE będą konkurowały ze sobą chociażby najpopularniejsze instalacje wiatrowe i fotowoltaiczne, które ze względu na swoje parametry techniczne nie mogą startować w innego rodzaju aukcjach $\mathrm{OZE}^{18}$. W ramach tych aukcji będą również konkurować różnego rodzaju instalacje hybrydowe, o których mowa w art. 2 pkt 11a u.o.z.e., o ile ich parametry techniczne nie pozwolą im zakwalifikować się do innego rodzaju aukcji OZE. Ze względu zatem na najbardziej otwarty katalog instalacji mogących uczestniczyć w tych aukcjach, a także uczestnictwo w niej instalacji fotowoltaicznych i wiatrowych, konkurencja $w$ ramach tego rodzaju aukcji OZE będzie najbardziej zaciekła. Jak w każdego rodzaju aukcji OZE możliwość uzyskania wsparcia w głównej mierze będzie zależeć od poziomu ceny referencyjnej dla danej technologii OZE, a precyzyjniej - od poziomu tej ceny, z którego skłonny jest zrezygnować dany inwestor chcący uzyskać wsparcie w ramach aukcji OZE. Niemniej w tych aukcjach OZE wpływ na poziom konkurencji pomiędzy poszczególnymi projektami, oprócz poziomu oferowanych cen aukcyjnych, będą miały też parametry techniczne poszczególnych instalacji OZE. Należy bowiem pamiętać, że aukcje w ramach opisywanych "koszyków technologicznych” (rodzajów aukcji OZE) odbywać się będą odrębnie dla instalacji OZE o mocy do $1 \mathrm{MW}$ i powyżej $1 \mathrm{MW}$. Owe parametry technologiczne mogą spowodować, że poszczególne technologie OZE będą bardziej predestynowane do uczestnictwa w aukcjach o wskazanych powyżej przedziałach mocy elektrycznej. Przykładowo, instalacje wiatrowe co do zasady składają się z kilku siłowni wiatrowych, z których każda dysponuje mocą powyżej $1 \mathrm{MW}$, co w naturalny sposób skłania do uczestnictwa w aukcji dla instalacji innych powyżej $1 \mathrm{MW}$. Natomiast instalacje fotowoltaiczne ze względu na wyższy poziom możliwej do zaoferowania ceny aukcyjnej korzystniej będzie formować w instalacje OZE nieprzekraczające mocy zainstalowanej elektrycznej na poziomie $1 \mathrm{MW}$. W związku z powyższym wydaje się, że aukcje dla instalacji innych powyżej 1 MW zostaną zdominowane przez instalacje wiatrowe oraz hybrydowe, natomiast aukcje dla instalacji innych poniżej $1 \mathrm{MW}$ w naturalny sposób zostaną zagospodarowane przez instalacje fotowoltaiczne oraz ewentualnie małe instalacje hybrydowe, które nie uzyskają parametrów technicznych

${ }^{18} \mathrm{~W}$ tym zakresie należy zastrzec, że instalacje te będą mogły rywalizować w aukcjach kwalifikowanych podmiotowo, a więc organizowanych dla członków spółdzielni energetycznych oraz klastrów energii. 
umożliwiających im wzięcie udziału w aukcji dla instalacji stabilnych, o których mowa w art. 73 ust. $3 a$ pkt 1 u.o.z.e. Należy przy tym pamiętać, że tak jak w przypadku pozostałych "koszyków technologicznych", charakteryzujących się znaczącym stopniem konkurencyjności, wpływ na możliwość wygrania aukcji przez daną instalację, oprócz zaoferowania niższej ceny aukcyjnej, ma także możliwość uzyskania pomocy publicznej z innych źródeł niż aukcja OZE. Dokonanie takiego zabiegu nie tylko pozwoli na zmaksymalizowanie łącznego poziomu pomocy publicznej, ale także zwiększy prawdopodobieństwo wygrania aukcji dzięki konieczności jeszcze większego obniżenia zaproponowanej ceny aukcyjnej danego projektu instalacji OZE.

Na koniec prowadzonych rozważań należy wskazać, że w ramach aukcji OZE narażonych na największą konkurencję ustawodawca nie zawarł żadnego mechanizmu przeciwdziałającego oferowaniu przez wytwórców zaniżonych, a przez to nieracjonalnych cen mających jedynie zapewnić wygranie aukcji OZE. W ograniczonym zakresie chodzi zatem o zminimalizowanie zjawiska określanego jako underbidding ${ }^{19}$, w którym poziom ceny za wytwarzanie energii elektrycznej ustalonej w ramach zwycięskiej aukcji nie pozwala na opłacalne prowadzenie tego rodzaju działalności gospodarczej, co może doprowadzić do niewybudowania danego projektu instalacji OZE po wygraniu aukcji OZE, a w konsekwencji do niezrealizowania celu wynikającego z polityki klimatyczno-energetycznej UE.

\section{Podsumowanie}

Przeprowadzone w niniejszym opracowaniu badania pozwalają stwierdzić, że ustawodawca przewidział możliwość przeprowadzenia przez Prezesa URE aż 56 rodzajów odrębnych aukcji OZE. Aukcje te przeprowadza się odrębnie, biorąc pod uwagę zarówno termin pierwszego wytworzenia energii elektrycznej, co pozwala wyróżnić instalacje stare, które po raz pierwszy wytworzyły energię elektryczną przed dniem 1 lipca 2016 r., oraz instalacje nowe, które wytwarzanie energii elektrycznej

${ }^{19}$ Zob. W. Szopiński, Wady i zalety przyjętych rozwiazań prawnych dotyczacych aukcji na wytwarzanie energii elektrycznej ze źródet odnawialnych, http://www.cire.pl/ item,129531,2,1,2,0,290038,0, wady-i-zalety-przyjetych-rozwiazan-prawnych-dotyczacych-aukcji-na-wytwarzanie-energii-elektrycznej-ze-zrodel-odnawialnych.html\#komentarz (dostęp: 17 I 2017). 
rozpoczęły, począwszy od wskazanej powyżej daty. Analiza tekstu normatywnego pozwoliła także wyróżnić zarówno stare, jak i nowe zmodernizowane instalacje OZE, dla których ustawodawca również przewidział konieczność organizowania odrębnych aukcji OZE. Ponadto, ze względu na skalę prowadzonej działalności, wytwórcy rywalizują między sobą w odrębnych aukcjach OZE organizowanych dla instalacji o mocy zainstalowanej elektrycznej powyżej oraz poniżej $1 \mathrm{MW}$. Niemniej Ustawą z dnia 22 czerwca 2016 r. o zmianie ustawy o odnawialnych źródłach energii oraz niektórych innych ustaw wprowadzono dalszy podział możliwych do przeprowadzenia aukcji OZE, tak aby poszczególne rodzaje instalacji OZE rywalizowały między sobą w wyodrębnionych, ze względu na parametry techniczne oraz przesłanki podmiotowe, aukcjach OZE, w doktrynie określanych mianem "koszyków technologicznych". Dokonana w niniejszym opracowaniu szczegółowa analiza wszystkich rodzajów aukcji OZE opisanych w art. 73 ust. 3a pkt 1-7 u.o.z.e. pozwala na wskazanie, jakiego rodzaju instalacje OZE mogą brać udział w poszczególnych rodzajach aukcji OZE. W przypadku niektórych rodzajów aukcji kluczową rolę mają parametry techniczne związane z poziomem emisji $\mathrm{CO}_{2}$ i stopniem wykorzystania mocy zainstalowanej elektrycznej, a także rodzaj wykorzystywanego źródła energii. Natomiast inne aukcje kwalifikowane są podmiotowo, a więc ze względu na rodzaj podmiotów mogących wziąć udział w takiej aukcji. Chodzi tu przede wszystkim o członków spółdzielni energetycznych oraz członków klastra energii. $W$ tym zakresie należy również wskazać, że proces kształtowania się przepisów prawnych umożliwiających prowadzenie działalności gospodarczej w formie klastra energii lub spółdzielni energetycznych nadal trwa, a powstające $\mathrm{w}$ tym zakresie inicjatywy mają jedynie charakter pilotażowy.

Warto też podkreślić, że poszczególni wytwórcy dysponujący różnymi instalacjami OZE mogą brać udział w więcej niż jednym rodzaju aukcji OZE, jeżeli tylko będą w stanie spełnić parametry poszczególnych aukcji OZE. W ramach przykładu można wskazać, że wytwórca dysponujący projektem biogazowni rolniczej może wziąć udział zarówno w aukcji dla instalacji stabilnych, o których mowa w art. 73 ust. 3a pkt 1 u.o.z.e., jak i w aukcji dedykowanej jedynie biogazowniom rolniczym, o których mowa w art. 73 ust. $3 a$ pkt 6 u.o.z.e. Niezależnie od tego, jeżeli wytwórca ten jest nadto członkiem klastra energii lub spółdzielni energetycznej, także może wziąć udział w aukcjach dedykowanych jedynie dla takich podmiotów. Podział wszystkich technologii OZE 
oraz przyporządkowanie ich do poszczególnych rodzajów aukcji OZE prowadzi do uprzywilejowania preferowanych przez ustawodawcę odnawialnych źródeł energii. Ponadto $\mathrm{w}$ ramach tych podziałów można wyróżnić poszczególne technologie, których szansa na wygranie danej aukcji znacząco wzrasta, dlatego tak ważna jest szczegółowa analiza prawna poszczególnych rodzajów aukcji OZE.

Niezależnie od powyższego możliwość przeprowadzenia poszczególnych rodzajów aukcji OZE uzależniona jest przede wszystkim od ilości i wartości energii elektrycznej przyporządkowanej przez Radę Ministrów do konkretnego rodzaju aukcji, którą określa rozporządzenie wolumenowe, i to w głównej mierze od tych uregulowań będzie zależeć, jakiego rodzaju instalacje OZE będą mogły uczestniczyć w danej aukcji OZE. Wśród rozporządzeń wykonawczych istotną rolę odgrywa również rozporządzenie ministra właściwego w sprawach energii, określające poziom maksymalnej ceny w złotych za 1 MWh energii elektrycznej. Istotna rola owych rozporządzeń wykonawczych, wydawanych w poszczególnych latach, w których będzie przeprowadzana aukcja OZE, zwiększa znaczenie Rady Ministrów oraz ministra właściwego $\mathrm{w}$ sprawach energii $\mathrm{w}$ sprawach $\mathrm{z}$ zakresu regulacji sektora elektroenergetycznego. Kluczowa pozycja Rady Ministrów w zakresie realizacji polityki państwa w obszarze energetyki odnawialnej związana $z$ udostępnianiem wolumenu energii na aukcje OZE czyni ten organ zasadniczo odpowiedzialnym za zrealizowanie wiążących Polskę celów wynikających z polityki klimatyczno-energetycznej UE. Jeżeli bowiem aukcje OZE nie będą umożliwiały wybudowania oraz utrzymania określonej ilości różnego rodzaju instalacji OZE, przedmiotowe cele mogą nie zostać zrealizowane.

\section{TYPES OF AUCTION INVOLVING ELECTRIC ENERGY PRODUCED FROM RENEWABLE SOURCES IN THE LIGHT OF THE PROVISIONS OF THE ACT ON RENEWABLE ENERGY SOURCES}

\section{S u m ma ry}

After an analysis of certain legal texts, the authors have established that under Polish law the President of the Energy Regulatory Office may conduct 56 different types of auctions for generators of the electric energy from renewable sources (RSE). For each individual RSE installation complying with the RES parameters a separate auction may be carried. One RSE installation may take part in several RSE auctions provided it satisfies the parameters of each individual installation. These parameters concern 
both the premises connected with the start-up process (the commencement of the production of electric energy) of a given installation and the premises of technical nature such as carbon dioxide emission or the level of the installation capacity used, as well as premises of a subjective character regarding individual producers participating in the auction. A detailed analysis of all types of RSE auctions described in the Act of 20 February 2015 on renewable sources of energy allows to determine which types of installation may take part in individual actions. However, of key importance from the point of view of the possibility of a RSE auction to be carried are secondary regulations which allow the Council of Ministers to determine individual types of RSE auctions in which the volume of energy, subject of the auction, will be made available. Consequently the Council of Ministers which runs the State policy within the area of RSE has become essentially responsible not only for the possibility of conducting an RSE auction, but also for the implementation of the EU climate and energy policy which is also binding upon Poland.

Keywords: electric energy - renewable sources of energy (RSE) - RSE auctions RSE support system 